\begin{tabular}{|c|c|c|}
\hline Beitr. Ent. & Keltern & ISSN 0005-805X \\
\hline $\mathbf{5 8}(2008) 2$ & S. $455-470$ & 15.11 .2008 \\
\hline
\end{tabular}

\title{
Four new species and additional records of Palaearctic Sunius, with two new synonymies
}

\section{(Coleoptera: Staphylinidae: Paederinae)}

With 40 figures and 1 map

\section{VOLKer Assing}

\section{Summary}

Four species of Sunius STEPHENS are described and illustrated: S. tronqueti sp. n. (Spain: Sierra Nevada), S. filabresicus sp. n. (Spain: Sierra de los Filabres), S. gadoricus sp. n. (Spain: Sierra de Gádor), and S. kastcheevi sp. n. (Kazakhstan). Two synonymies are proposed: S. melanocephalus (FABricius, 1793) =S. anatolicus Assing, 1995, syn. n., S. claviceps (Reitter, 1908) = Sunius bogdoensis Grebennikov, 2001, syn. n. Additional records of 24 (sub-)species are reported from the Palaearctic region.

Key words

Coleoptera, Staphylinidae, Paederinae, Sunius, Palaearctic region, taxonomy, new species, new synonymies, additional records

\section{New species}

Sunius tronqueti sp. n., S. filabresicus sp. n., S. gadoricus sp. n., S. kastcheevi sp. n.

\section{Zusammenfassung}

Vier Sunius-Arten werden beschrieben und abgebildet: S. tronqueti sp. n. (Spanien: Sierra Nevada), S. filabresicus sp. n. (Spanien: Sierra de los Filabres), S. gadoricus sp. n. (Spanien: Sierra de Gádor) und S. kastcheevi sp. n. (Kasachstan). Zwei Namen werden synonymisiert: S. melanocephalus (FABricius, 1793) = S. anatolicus Assing, 1995, syn. n., S. claviceps (Reitter, 1908) = Sunius bogdoensis Grebennikov, 2001, syn. n. Weitere Nachweise von 24 Arten und Unterarten werden aus der Paläarktis gemeldet.

\section{Introduction}

According to a recent revision, the speciose paederine genus Sunius STEPHENS, 1829 is represented in the Western Palaearctic region and Middle Asia by 94 species and 3 subspecies (Assing 2008). Considering the fact that more than half of them were described only in the past six years, it seemed likely that more novelties remained to be discovered.

Since the completion of the last instalment of the revision, more material, including types, has become available from various public and private collections, as well as from recent field trips. Besides numerous additional records, this material yielded no less than four new species. Also, two new synonymies were discovered, so that the Western Palaearctic and Middle Asian Sunius fauna now includes 97 species and 2 subspecies. 


\section{Material and methods}

The material referred to in this study is deposited in the following public institutions and private collections:

$\begin{array}{ll}\text { MNHNP } & \text { Museum National d'Histoire Naturelle, Paris (A. Taghavian) } \\ \text { NHMW } & \text { Naturhistorisches Museum Wien (H. Schillhammer) } \\ \text { OÖLL } & \text { Oberösterreichisches Landesmuseum Linz (F. Gusenleitner) } \\ \text { ZIN } & \text { Zoological Institute, Russian Academy of Sciences, St. Petersburg (B. Kataev, via V. Gusarov) } \\ \text { cAss } & \text { author's private collection } \\ \text { cKas } & \text { private collection Vitaly Kastcheev, Almaty } \\ \text { cTro } & \text { private collection Marc Tronquet, Molitg-les-Bains } \\ \text { cSch } & \text { private collection Michael Schülke, Berlin } \\ \text { cSha } & \text { private collection Alexey Shavrin, Irkutsk }\end{array}$

The morphological studies were carried out using a Stemi SV 11 microscope (Zeiss Germany) and a Jenalab compound microscope (Carl Zeiss Jena). For the photographs a digital camera (Nikon Coolpix 995) was used.

Head length was measured from the anterior margin of the frons to the posterior margin of the head, elytral length at the suture from the apex of the scutellum to the posterior margin of the elytra.

The map was generated using the online generic mapping tool (GMT) of the Geomar website at www. aquarius.ifm-geomar.de/omc.

\section{Results}

Below, only those additional records of described species are discussed that significantly expand the known distributions or that are remarkable for other reasons. For more details on the identification, zoogeography, and ecology of the species see Assing (2008). The species sections are arranged according to species groups; for details see Assing (2008).

\section{Sunius propinquus (BRISOUT DE BARNEVILLE, 1867)}

Material examined:

Portugal: 1 ex., Coimbra, leg. Paulino (NHMW). Spain: 1 ex., Castilla-La Mancha, Sierra de Segura, ca. $15 \mathrm{~km}$ W Yeste, Calar de Sima, $38^{\circ} 21^{\prime} \mathrm{N}, 02^{\circ} 29^{\prime} \mathrm{W}, 1430 \mathrm{~m}$, deep canyon with Corylus, grass, moss, and ferns, sifted, 15.III.2008, leg. Assing (cAss); 1 ex., Madrid, Tres Cantos, Arroyo de Tejada, VIII.2001, leg. Anichtchenko (cSha); 2 exs., Madrid, Casa del Campo (NHMW). France: 1 ex., Nord, Lille, leg. Pandellé (NHMW); 1 ex., Centre, Loiret, Gien, leg. Pyot (NHMW); 3 exs., Provence, Var, La Seyne, leg. Tholin (NHMW). Italy: 1 ex., Liguria, Laigueglia, 8.V.1959, leg. Liberti (NHMW).

\section{Sunius ovaliceps (FAUVEL, 1878)}

Material examined:

Algeria: 2 exs., Mouzaïa, IV.1909 (NHMW, cAss); 1 ex., locality not specified (NHMW). Morocco: 1 ex., Arsila, leg. Quedenfeldt (NHMW); 1 ex., Tetuan, leg. Quedenfeldt (NHMW); 1 ex., locality not specified (NHMW). Spain: 10 exs., Murcia, Jumilla, 1200 m, 1.III.2003, leg. Lencina (cAss); 1 ex., Castilla-La Mancha, Sierra de Segura, Sierra de Cujón, $38^{\circ} 28^{\prime} \mathrm{N}, 02^{\circ} 21^{\prime} \mathrm{W}, 1460$ m, grass and moss near rocks sifted, 15.III.2008, leg. Assing (cAss); 3 exs., Cuenca (NHMW); 2 exs., Andalucía, Algeciras (NHMW); 1 ex., Andalucía, locality not specified, leg. Reitter (NHMW); 1 ex., Sierra de Guadarrama, leg. Moczarski (NHMW); 1 ex., 
Madrid, Casa del Campo (NHMW); 1 ex., Madrid env., leg. Moczarski (NHMW); 2 8s., Castilla-León, Palencia, leg. Paganetti (NHMW); 1 ex., Castilla-León, León, Caboalles, leg. Paganetti (NHMW); 1 ex., Navarra, Artajona, $42.63^{\circ} \mathrm{N}, 1.78^{\circ} \mathrm{W}, 470 \mathrm{~m}, 20 . \mathrm{VIII} .2008$, leg. Andújar \& Arribas (cAss).

\section{Sunius melanocephalus (FABRICIUS, 1793)}

Sunius anatolicus Assing, 1995: 269; syn. n.

Material examined:

Czech Republic: 2 exs., Praha, leg. Skalitzky (NHMW); 1 ex., Praha (NHMW); 1 ex., Brandýs n. L., 10.V.1896 (NHMW); 1 ex., Brandýs n. L. (NHMW). Austria: 1 ex., Wiener Wald, Hadersdorf, leg. Skalitzky (NHMW). Caucasus region: 3 exs., "Kaukas", leg. Leder (NHMW, cAss). Turkey: 5 exs. [partly teneral],

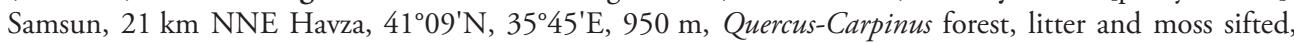
19.VII.2008, leg. Assing \& Schülke (cAss, cSch); 1 ex., Samsun, 26 km NNE Havza, 41 ${ }^{\circ} 11^{\prime} \mathrm{N}, 35^{\circ} 46^{\prime} \mathrm{E}$, $800 \mathrm{~m}$, Quercus-Carpinus forest, litter sifted, 19.VII.2008, leg. Schülke (cSch); 1 ex., Samsun, 31 km NE Havza, $41^{\circ} 12^{\prime} \mathrm{N}, 35^{\circ} 52^{\prime} \mathrm{E}, 670 \mathrm{~m}$, Fagus forest, litter sifted, 19.VII.2008, leg. Assing (cAss); 10 exs. [partly

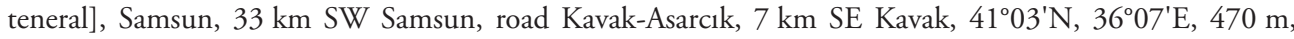
Quercus-Carpinus forest, litter sifted, 20.VII.2008, leg. Assing \& Schülke (cAss, cSch); 1 ex., Isparta, Sultan Dağları, W Cankurtaran, 38 $15^{\prime} \mathrm{N}, 31^{\circ} 23^{\prime} \mathrm{E}, 1550 \mathrm{~m}$, 17.IV.2008, leg. Brachat \& Meybohm (cAss); 9 exs., locality not specified ["Lyciae Taurus", "Lyc. Taurus", etc.] (NHMW).

Sunius anatolicus was originally described as a distinct species and subsequently considered a subspecies of $S$. melanocephalus (Assing 1995, 2008). The types of $S$. anatolicus are distinguished from non-Turkish $S$. melanocephalus by a slightly different shape of the apex of the aedeagus and by usually longer elytra and hind wings. The distribution was postulated to be confined to southwestern Anatolia (Assing 1995). In the meantime, however, numerous specimens with intermediate character states have been examined, and specimens with a similar external and sexual morphology as the types of $S$. anatolicus have also been recorded from various localities in northern Anatolia, so that the earlier hypothesis that $S$. anatolicus should represent a distinct (sub-) species is implausible also for zoogeographic reasons. Based on the data now available, it appears more likely that the observed differences are an expression of intraspecific variation. Consequently, $S$. anatolicus is here placed in the synonymy of $S$. melanocephalus.

\section{Sunius fallax (LOKAY, 1919)}

Material examined:

Austria: 4 exs., Neusiedler See, leg. Schuster (NHMW); 1 ex., Neusiedler See (NHMW). Hungary: 1 ex., Neusiedler See (NHMW). Romania: 1 ex., Comana Vlasca, leg. Montandon (NHMW). BosniaHerzegovina: 5 exs., Čelič, leg. Reiss (NHMW, cAss); 1 ex., Travnik (NHMW). Greece: 1 ex., Crete, Kalivos env., 70-340 m, V.2008, leg. Schimmel (cAss).

\section{Sunius brevipennis brevipennis (WoLlaston, 1864)}

Material examined:

Canary Islands: Tenerife: 1 ex., Anaga, Casa Carlos, 13.VI.1998, leg. Filipino (NHMW); 1 ex., Las Mercedes, 3.IV.1949, leg. Lindberg (NHMW).

\section{Sunius brevipennis gomerensis AssING, 2008}

Material examined:

Canary Islands: Gomera: 4 exs., locality not specified, leg. Fernandez (NHMW). 


\section{Sunius brevipennis canariensis (BERNHAUER, 1928)}

Material examined:

Canary Islands: Gran Canaria: 1 ex., Las Lagunetas, 1.IV.1949, leg. Lindberg (NHMW).

\section{Sunius fernandezi (HERNÁNDEZ \& GARCíA, 1982)}

Material examined:

Canary Islands: Tenerife: 2 exs., locality not specified, leg. Fernandez (NHMW).

\section{Sunius fulgocephalus (COIFFAIT, 1970)}

Material examined:

Azerbaijan: 5 exs., Ordubad, leg. Leder \& Reitter (NHMW); 4 exs., Lenkoran, leg. Leder \& Reitter (NHMW).

\section{Sunius bicolor (OLIVIER, 1795)}

Material examined:

Spain: 1 ex., Navarra, Orgi Robledad, 6.I.2001, leg. Anichtchenko (cSha); 1 ex., Valencia, Alicante, Pinoso, Humedal "El Prado", light, 26.VII.2008, leg. Lencina \& Sánchez (cAss); 1 ex., Valencia, Alicante, NE Benissa, Alcalali, Rio Jalon, $38^{\circ} 45^{\prime} \mathrm{N}, 00^{\circ} 03^{\prime} \mathrm{W}, 400 \mathrm{~m}$, river bank, 10.VIII.2008, leg Forcke (cAss); 1 ex., Andalucía, Granada, rio Darro, barranco de Teatino, 6.II.2005, leg. Anichtchenko (cSha); 1 ex., Andalucía, Jaén, Linarejos, Sierra de Cazorla, 1.XI.2006, leg. Baena (cAss). France: 2 exs., Rhône-Alpes, Savoie, Belmont, leg. Poussielgue (NHMW); 4 exs., Midi-Pyrénées, Tarn, Salvages, leg. Savoy (NHMW). Germany: 1 ex., Berlin (NHMW). Austria: 1 \%, Wien, Bisamberg (NHMW). Czech Republic: 3 exs., Brandýs n. L. (NHMW, cAss).

\section{Sunius algiricus (COIFFAIT, 1970)}

Material examined:

Tunisia: 4 exs., Fernana (NHMW, cAss); 2 exs., Souk-el-Arba (NHMW).

\section{Sunius puglianus (COIFFIT, 1961)}

Material examined:

Italy: 1 ex., Puglia, Gioia del Colle, 20.IV.1944, leg. Focarile (NHMW).

\section{Sunius brachypterus (GEMMINGER \& HAROLD, 1868)}

Material examined:

France or Spain: 1 ex., "Pyr. or." (NHMW).

\section{Sunius simoni (QUEDENFELDT, 1881)}

Material examined:

Morocco: 1 ex., Tetuan (NHMW). Spain: 1 ex., Andalucía, Algeciras (NHMW).

\section{Sunius fultus Assing, 2003}

Material examined:

Morocco: 1 ex., Taza, leg. Breit (NHMW). 
Sunius discretus Assing, 2008

Material examined:

Tunisia: 5 exs., Le Kef (NHMW, cAss).

\section{Sunius calatravae Assing, 2008}

Material examined:

Spain: 4 exs., Ciudad Real, Pozuelo de Calatrava, leg. Fuente (NHMW, cAss).

\section{Sunius tronqueti sp. $\mathrm{n}$.}

(Figs 1-9, Map 1)

\section{Type material:}

Holotype $\sigma^{\star}:$ : Espagne, Almeria, Sierra Nevada, Chullo verst. N-O., sous les pierres, 2100/2550, M. Tronquet, 17/04/2000 / Holotypus ơ Sunius tronqueti sp. n. det. V. Assing 2008" (cAss). Paratypes: 18 exs.: same data as holotype (cTro, cAss); 8 exs.: "Espagne, Almeria Sierra Nevada, laguna Seca, sous les pierres, 2250 m, M. Tronquet, 19/04/2000" (cTro, cAss).

\section{Description:}

Small species, 2.4-2.8 mm. Forebody as in Fig. 1. Coloration: forebody uniformly dark-yellowish; abdomen reddish-brown to dark brown, usually with the apex more or less distinctly paler; legs and antennae yellowish.

Head approximately as wide as long, weakly to distinctly dilated posteriad; punctation coarse and sparse; microsculpture absent; eyes less than $1 / 3$ the length of postocular region in dorsal view (Fig. 1).

Pronotum slightly narrower than head and weakly oblong; punctation as coarse as that of head, but denser (Fig. 1); microsculpture absent.

Elytra approximately as wide, and at suture approximately 0.75 times as long as pronotum; punctation much finer than that of pronotum, dense, and somewhat ill-defined. Hind wings reduced.

Abdomen approximately 1.1 times as wide as elytra, widest at segment VI; punctation fine and moderately dense; interstices with shallow microsculpture; posterior margin of tergite VII without palisade fringe.

$0^{\text {t: }}$ sternite VII with weakly concave posterior margin, pubescence unmodified; sternite VIII posteriorly with rather deep and relatively narrow incision, otherwise unmodified (Fig. 2); aedeagus shaped as in Figs 3-6; ventral process distinctly longer than basal part of aedeagus; internal sac with a series of stout sclerotised spines (Figs 7-9).

\section{Etymology:}

The species is dedicated to Marc Tronquet, a most enthusiastic student of the staphylinid fauna of the Eastern Pyrenees and a gifted photographer, who collected the type material.

\section{Comparative notes:}

Using the key in Assing (2008), this species would key out at couplet 82 together with the highly similar S. nevadensis (CoIfFAIT). From this species, S. tronqueti is distinguished by paler average coloration and the uniformly yellowish forebody $(S$. nevadensis: head usually slightly darker than 


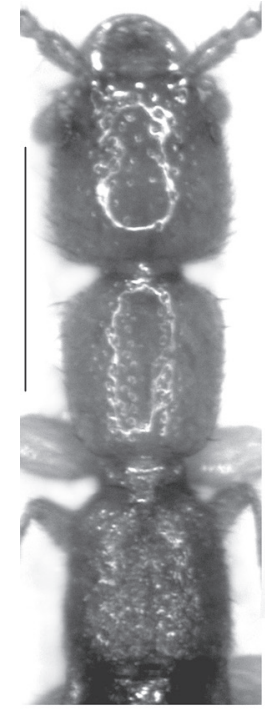

1

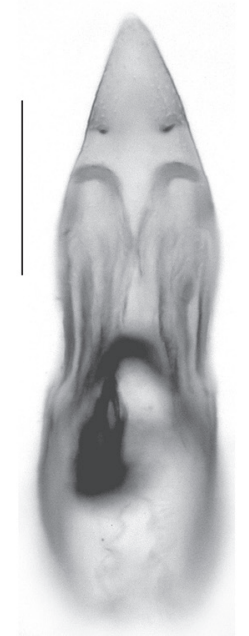

6
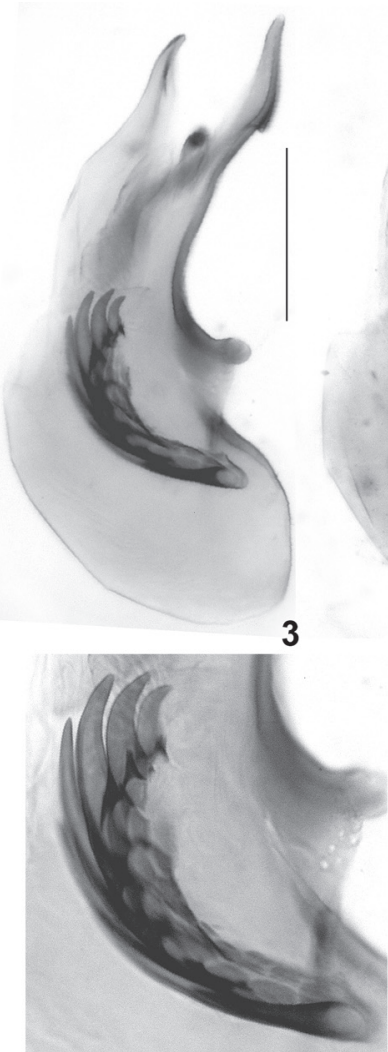

7

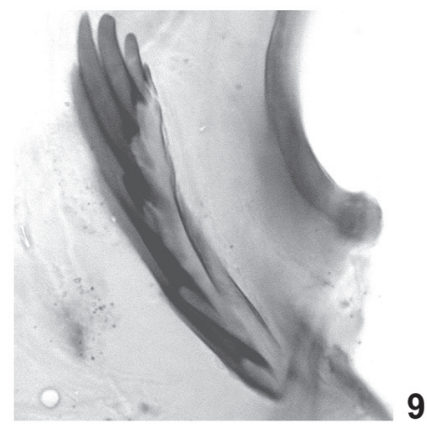

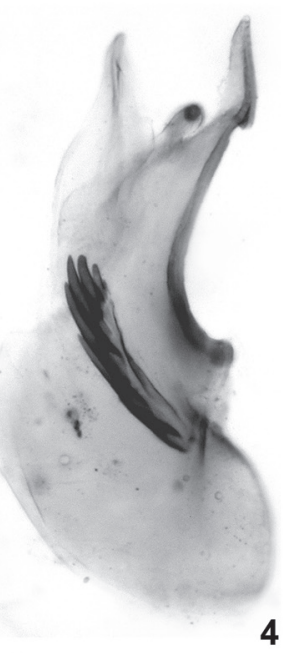

4

5

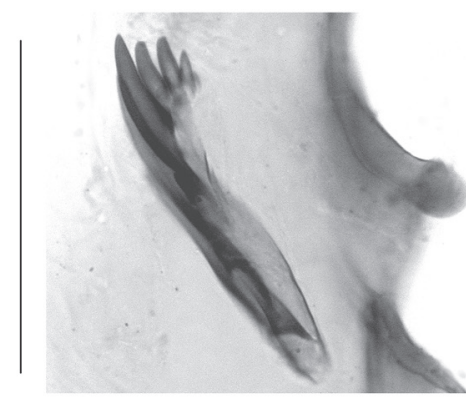

8

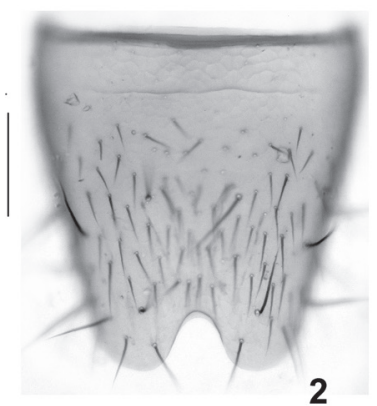

Figs 1-9: Sunius tronqueti sp. n.: forebody (1); male sternite VIII (2); aedeagus in lateral and in ventral view (3-6); internal structures of aedeagus in lateral view (7-9). Scale bars: 1: $0.5 \mathrm{~mm}$; 2-9: 0.1 mm.

pronotum; abdomen dark brown to blackish-brown, with the apex not distinctly paler), by the narrower and deeper posterior excision of the male sternite VIII, by the more strongly curved ventral process of the aedeagus, the shorter apex of the ventral process, as well as by the shape of the internal structures of the aedeagus (a longer series of stouter spines). For illustrations of S. nevadensis see Assing (2008). 


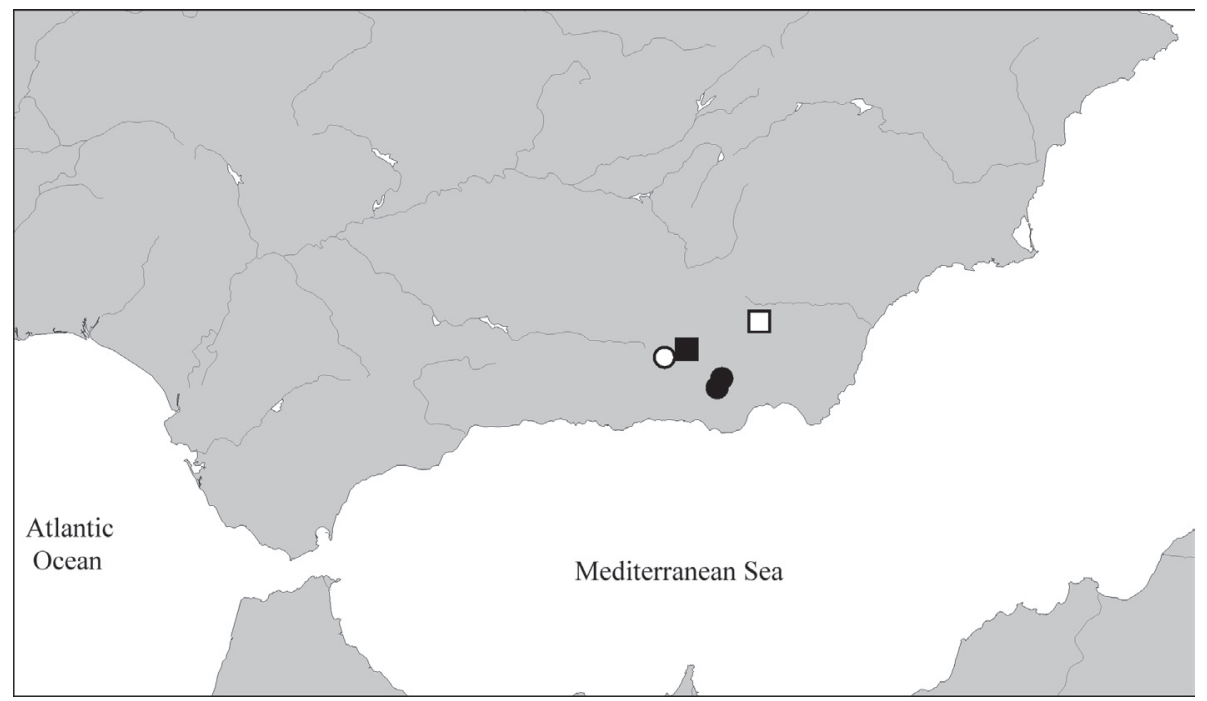

Map 1: The distribution of Sunius gadoricus sp. n. (filled circles), S. nevadensis (CoIfFaIT) (open circle), S. tronqueti sp. n. (filled square), and S. filabresicus sp. n. (open square) in southern Spain.

\section{Comment:}

The type material was previously identified as S. nevadensis (Assing 2008). Only when comparing the material of $S$. filabresicus (see below) with specimens from the Sierra Nevada did I become aware of the fact that the Sierra Nevada is apparently inhabited by two locally endemic Sunius species, S. nevadensis in the western and $S$. tronqueti in the eastern parts of the Sierra Nevada.

\section{Distribution and bionomics:}

The known distribution is confined to the northeastern slope of Chullo mountain and the adjacent Laguna Seca, to the east of the Puerto de la Ragua in the eastern Sierra Nevada (Map 1). The type specimens were collected under stones at altitudes between 2100 and $2550 \mathrm{~m}$.

\section{Sunius filabresicus sp. $\mathbf{n}$.}

(Figs 10-19, Map 1)

\section{Type material:}

Holotype $o^{\star}$ : E- Andalucía [15], Sierra de los Filabres, S Serón, $1800 \mathrm{~m}$, grassland, $37^{\circ} 15^{\prime} 44 \mathrm{~N}$, 02³0'30W, 19.III.2008, V. Assing / Holotypus o Sunius filabresicus sp. n. det. V. Assing 2008 (cAss). Paratypes: $8 \sigma^{\star} \sigma^{\star}, 10$ 우 오 : same data as holotype (cAss, cSch, OÖLL).

\section{Description:}

2.6-3.2 mm. Habitus as in Fig. 10. Coloration: forebody uniformly dark yellowish to reddishyellow; abdomen reddish-brown to dark brown, usually with the apex more or less distinctly paler; legs and antennae yellowish.

Head approximately as wide as long, weakly dilated posteriad; punctation coarse and sparse; microsculpture absent; eyes approximately $1 / 3$ the length of postocular region in dorsal view or slightly larger (Fig. 11). 


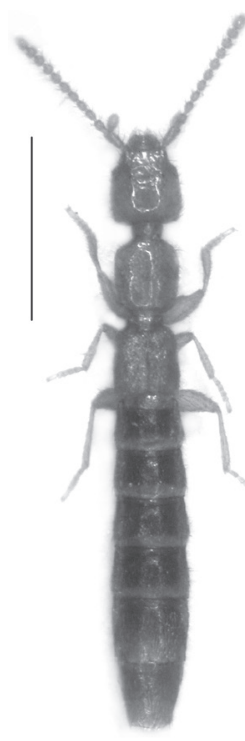

10
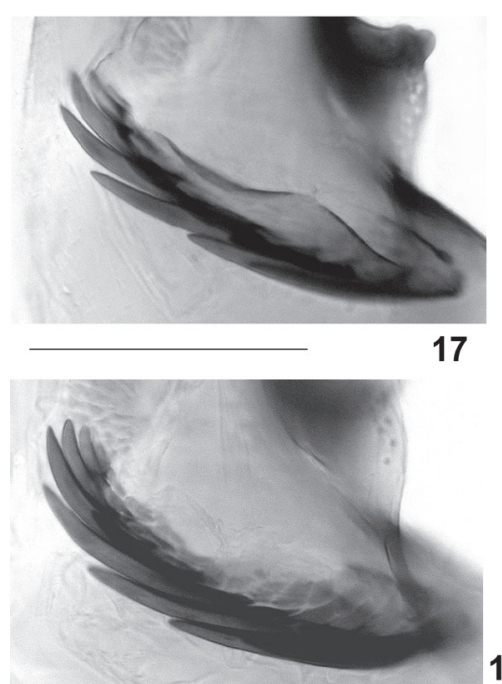

17

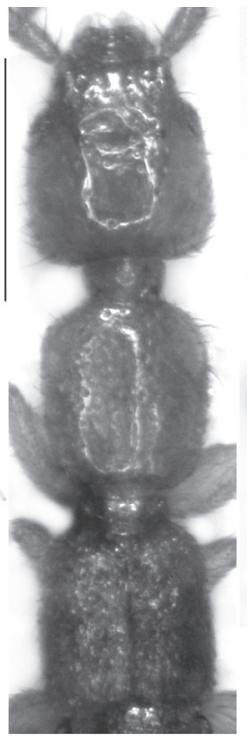

11

18

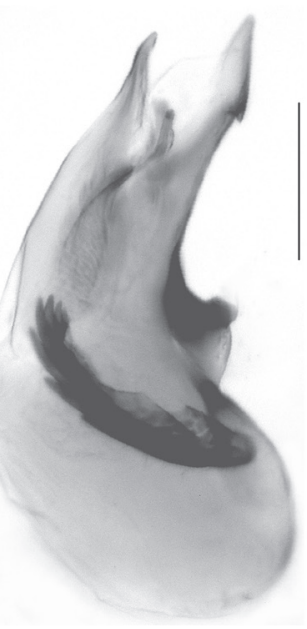

14

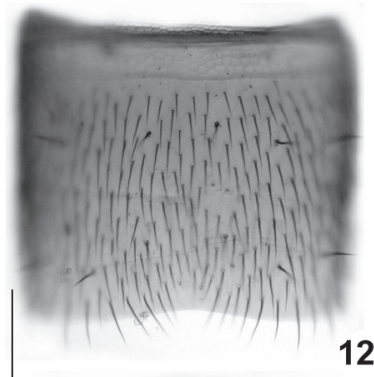

12

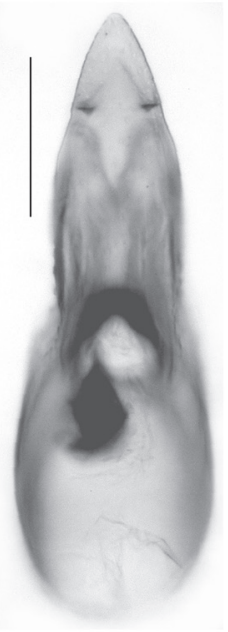

16

Figs 10-18: Sunius filabresicus sp. n.: habitus (10); forebody (11); male sternite VII (12); male sternite VIII (13); aedeagus in lateral and in ventral view (14-16); internal structures of aedeagus in lateral view (17-18). Scale bars: 10: $1.0 \mathrm{~mm}$; 11: $0.5 \mathrm{~mm}$; $12-18: 0.1 \mathrm{~mm}$.

Pronotum slightly narrower than head and weakly oblong; punctation as coarse as that of head, but denser (Fig. 11); microsculpture absent.

Elytra approximately as wide, and at suture 0.70-0.75 times as long, as pronotum; punctation much finer than that of pronotum, dense, and somewhat ill-defined. Hind wings reduced.

Abdomen approximately 1.1 times as wide as elytra, widest at segment VI (Fig. 10); punctation fine and moderately dense; interstices with shallow microsculpture; posterior margin of tergite VII without palisade fringe. 


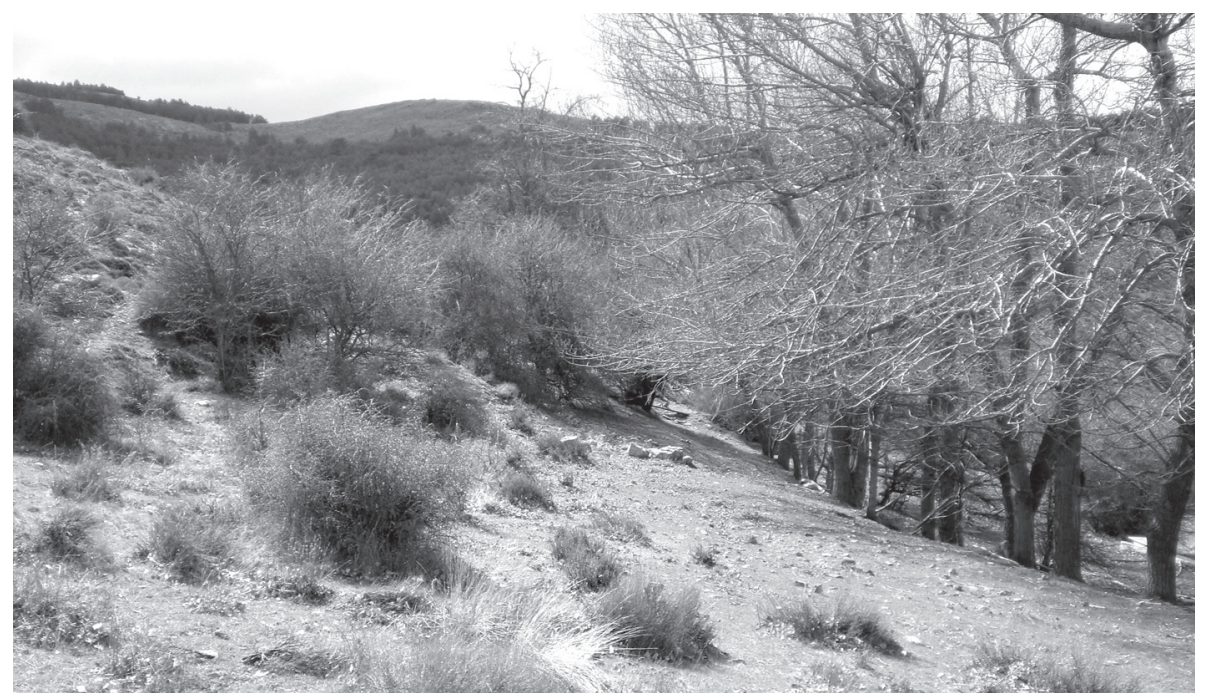

Fig. 19: Type locality of Sunius filabresicus sp. n.

$\sigma^{\star}$ : sternite VII with a weakly concave posterior margin, pubescence unmodified (Fig. 12); sternite VIII posteriorly with moderately deep and rather broadly concave incision, otherwise unmodified (Fig. 13); aedeagus shaped as in Figs 14-16; ventral process rather short, approximately as long as basal part; internal sac with a long series of long and slender sclerotised spines (Figs 17-18).

\section{Etymology:}

The name (adjective) derives from the name of the mountain range where the type locality is situated and where the species is probably endemic.

\section{Comparative notes:}

From the highly similar S. tronqueti, S. filabresicus is distinguished by slightly larger eyes, the broader and less deep posterior excision of the male sternite VIII, the more slender (in ventral view) and shorter ventral process of the aedeagus, as well as by the different position and shape (longer, more slender) of the spines in the internal sac. From $S$. nevadensis, it is separated by the paler average coloration, the slightly larger eyes, the more slender (in ventral view) and shorter ventral process of the aedeagus, and by the different position and shape of the internal structures of the aedeagus. For illustrations of $S$. nevadensis and to distinguish it from other Western Palaearctic Sunius species see the key in Assing (2008).

\section{Distribution and bionomics:}

As can be inferred from the restricted distributions of closely related congeners from the southern Mediterranean and by the reductions of eye size, wings, and pigmentation, the species is probably endemic to the Sierra de los Filabres (Map 1). The type specimens were collected under stones in a pasture and on a grassy slope at an altitude of $1800 \mathrm{~m}$ (Fig. 19).

\section{Sunius gadoricus sp. $\mathrm{n}$.}

(Figs 20-28, 40, Map 1)

\section{Type material:}

Holotype ơ: E - Andalucía [11], W Almeria, Sierra de Gádor, 1720 m, 3655'20N, 0247'53W, 17.III.2008, C. Andújar \& V. Assing / Holotypus ơ Sunius gadoricus sp. n. det. V. Assing 2008 
(cAss). Paratypes: $80^{\star} o^{\star}, 8$ 우: same data as holotype (cAss); 3 우 을 E - Andalucía [10], W Almeria, Sierra de Gádor, 1510 m, 36 56'45N, 0246'56W, 17.III.2008, C. Andújar \& V. Assing (cAss); $5 o^{\star} o^{\star}, 11$ 우: : E - Andalucía [14], W Almeria, Sierra de Gádor, $2220 \mathrm{~m}, 36^{\circ} 54^{\prime} 15 \mathrm{~N}$, 0249'37W, 18.III.2008, C. Andújar \& V. Assing (cAss, cSch, OÖLL).

\section{Description:}

2.7-3.4 mm. Habitus as in Fig. 20. Coloration: forebody uniformly dark-yellowish; abdomen yellowish-brown to brown, usually weakly contrasting with forebody; legs and antennae yellowish.

Head 1.02-1.14 times as long as wide, not distinctly dilated posteriad; punctation coarse and sparse; microsculpture absent; eyes approximately $1 / 3$ the length of postocular region in dorsal view (Fig. 21).

Pronotum slightly narrower than head and weakly oblong; punctation as coarse as that of head, but denser (Fig. 21); microsculpture absent.

Elytra approximately as wide and at suture approximately $0.75-0.80$ times as long as pronotum; punctation much finer than that of pronotum, dense, and somewhat ill-defined. Hind wings reduced.

Abdomen approximately 1.15 times as wide as elytra, widest at segment VI (Fig. 20); punctation fine and moderately dense; interstices with barely noticeable microsculpture; posterior margin of tergite VII without palisade fringe.

$\sigma^{\star}$ : sternite VII with weakly concave, almost truncate posterior margin, pubescence unmodified (Fig. 22); sternite VIII posteriorly with rather shallow incision, otherwise unmodified (Fig. 23); aedeagus shaped as in Figs 24-26; ventral process short, stout, and distinctly curved in lateral view; internal sac with a series of stout sclerotised spines (Figs 27-28).

\section{Etymology:}

The name (adjective) is derived from the name of the mountain where the species is probably endemic.

\section{Comparative notes:}

Using the key in Assing (2008), S. gadoricus would key out at couplet 82 together with S. nevadensis. Sunius gadoricus is distinguished from $S$. nevadensis by its paler average coloration (especially of the abdomen), the slightly larger eyes, the shallower posterior excision of the male sternite VIII, the much stouter ventral process (in ventral view) of the aedeagus, as well as by the different shape of the internal structures of the aedeagus. From S. tronqueti and S. filabresicus, it is reliably distinguished only by the shallow posterior excision of the male sternite VIII and by the morphology of the aedeagus (shape of ventral process and of internal structures). For illustrations of $S$. nevadensis and to distinguish it from other congeners see Assing (2008).

\section{Distribution and bionomics:}

The known distribution is confined to the Sierra de Gádor, a mountain range to the south of the Sierra Nevada (Map 1). The type specimens were collected under stones on grassland, on sparsely vegetated northern slopes, and near the edge of a snowfield (Fig. 40) at altitudes of 1510-2220 m.

\section{Sunius cordobanus AssING, 2008}

(Figs 29-35)

Material examined:

Spain: 9 exs., Córdoba, Sierra de Cabra, El Navazuelo Cabra, 4.IV.2007, leg. M. Baena (cAss). 


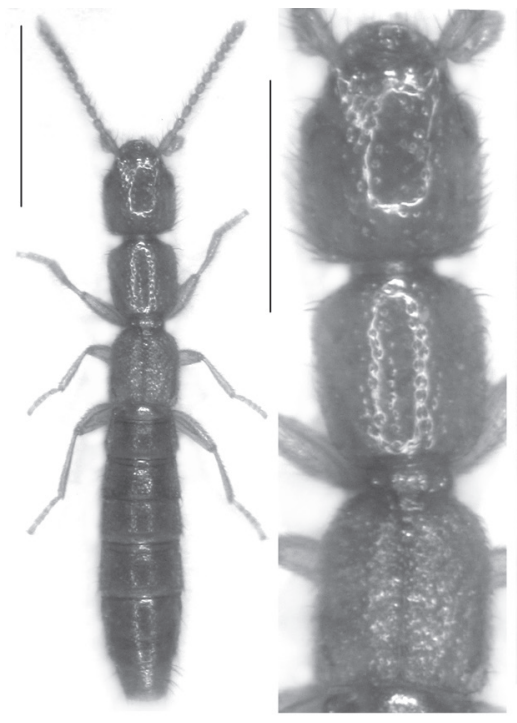

20

21

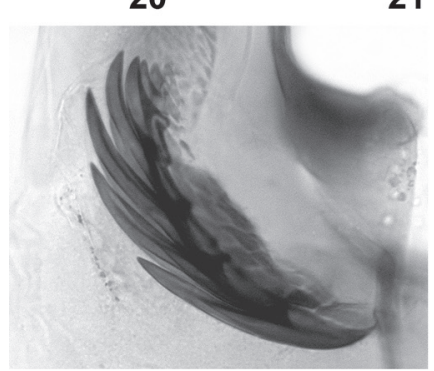

27

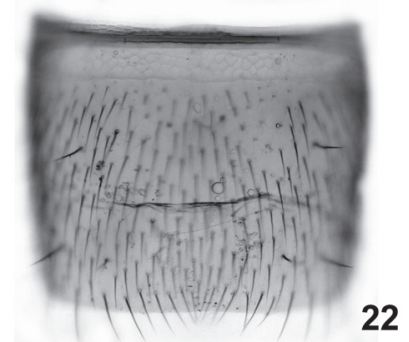

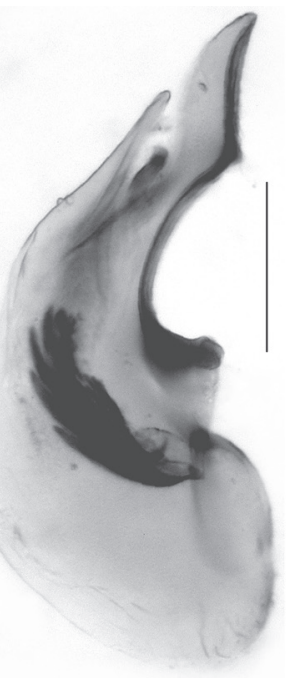

24

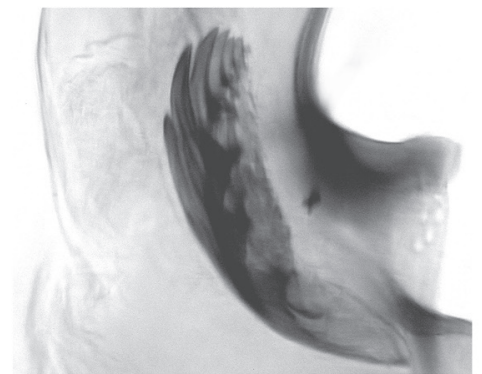

28

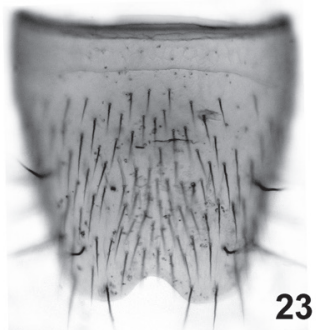

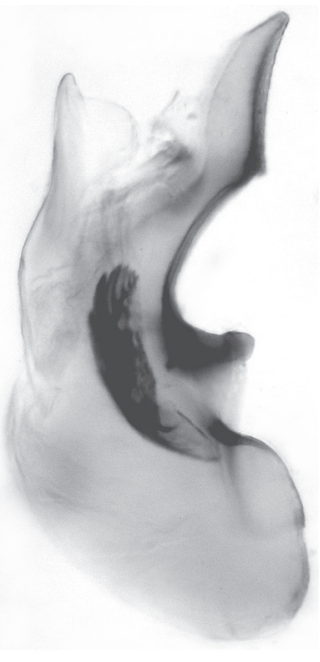

25

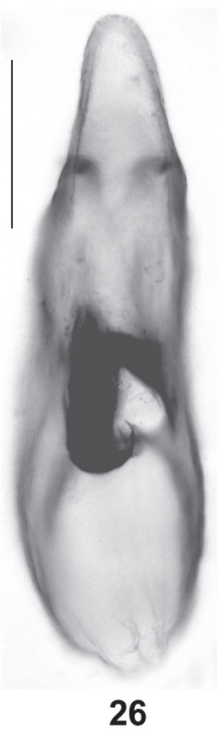

Figs 20-28: Sunius gadoricus sp. n.: habitus (20); forebody (21); male sternite VII (22); male sternite VIII (23); aedeagus in lateral and in ventral view (24-26); internal structures of aedeagus in lateral view (27-28). Scale bars: 20: $1.0 \mathrm{~mm}$; 21: $0.5 \mathrm{~mm}$; 22-28: $0.1 \mathrm{~mm}$.

One of the two paratypes is a male, not a female as indicated in the original description.

Previously, the species was known only from the type locality, the Sierra de Córdoba to the north of the town of Córdoba in Andalucía. In view of the fact that the species of the S. seminiger group are generally local endemics, it seems quite remarkable that the above material was collected in the Sierra de Cabra, which is separated from the Sierra de Córdoba by a broad and deep valley. However, a thorough comparison of the male primary and secondary sexual characters yielded 


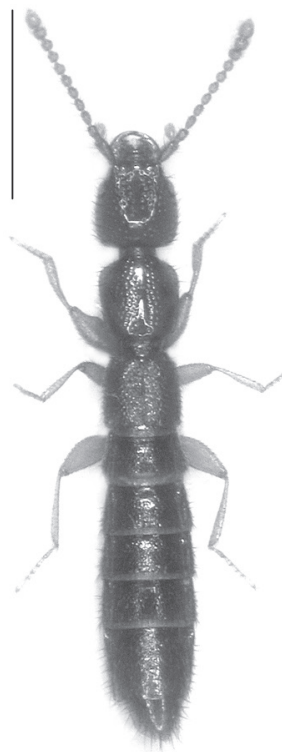

29

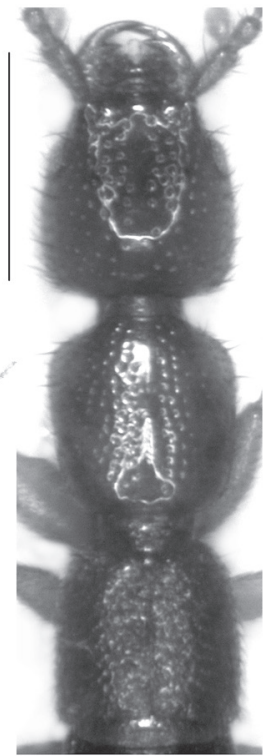

30
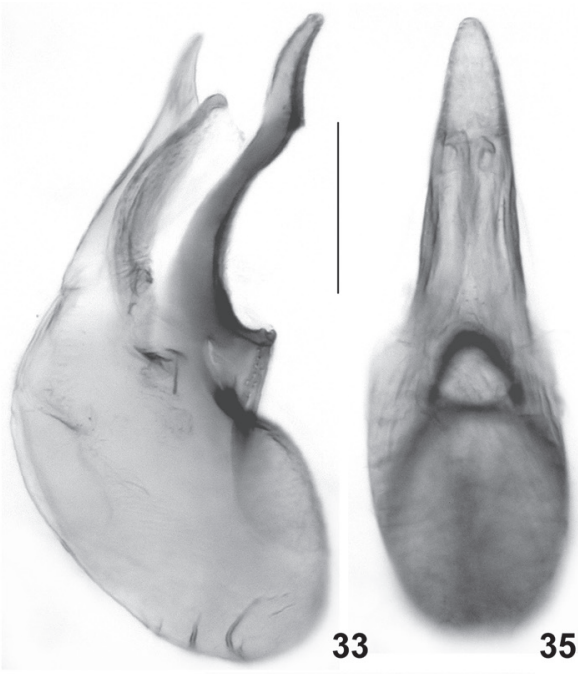

.
32

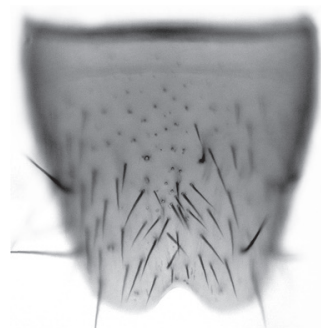

Figs 29-35: Sunius cordobanus Assing (Sierra de Cabra): habitus (29); forebody (30); male sternite VII (31); male sternite VIII (32); aedeagus in lateral and in ventral view (33-35). Scale bars: 29: $1.0 \mathrm{~mm}$; 30: $0.5 \mathrm{~mm}$; 31-32: $0.2 \mathrm{~mm}$; 33-35: $0.1 \mathrm{~mm}$.

no significant differences, suggesting that both populations are conspecific. For illustrations of the external and the male sexual characters of the specimens from the Sierra de Cabra see Figs 29-35.

\section{Sunius vaulogeri (COIFFAIT, 1973)}

Material examined:

Algeria: 10 exs., "Dj. Babor, de Vauloger / Collection H. Coiffait" (MNHNP, cAss). 
According to the original description of $S$. vaulogeri, the type material was collected in "Teniet el Had, Algérie", which is far away from the Djebel Babor. Since the available data suggest that the North African representatives of the S. seminiger group are all local endemics (Assing 2008), it seems probable that either the type material or the above specimens were mislabelled.

\section{Sunius baboricus Assing, 2008}

Material examined:

Algeria: 5 exs., Djebel Babor, leg. de Vauloger (MNHNP, cAss).

\section{Sunius nigrinus (EPPELSHEIM, 1892)}

\section{Additional type material examined:}

Medon picinus Bernhauer: Paralectotypes: 1 ex.: Margelan, Reitter / ex coll. Scheerpeltz / Cotypus Medon picinus Bernhauer (NHMW); 1 ex.: Margelan, Turkest. / ex coll. Scheerpeltz / Cotypus Medon picinus Bernhauer (NHMW); 1 ex.: Margelan, Staudinger / picinus Bernh. / ex coll. Luze / Cotypus Medon picinus Bernhauer (NHMW); 1 ex.: Margelan, Centralasien / nigrinus Brh. type, Staudinger / type / ex coll. Skalitzky / Typus Medon nigrinus [sic] Bernhauer / Typus Medon picinus Bernhauer (nom. nov. em.) (NHMW); 2 exs.: Turcmenien, Reitter. Leder. / propinquus Bris. / nigrinus Bernh. / vid. Bernh. / ex coll. Skalitzky / Cotypus Medon picinus Bernhauer (NHMW); 1 ex.: $\sigma^{\star} /$ Aulie Ata, Turkestan / nigrinus Brnh. Staudinger, type / ex coll. Scheerpeltz / Typus Medon nigrinus [sic] Bernhauer (NHMW).

Additional material examined:

Tajikistan: 2 exs., Karateghin mts., Saripul ["Sary-pul", $38^{\circ} 25^{\prime} \mathrm{N}, 70^{\circ} 08^{\circ} \mathrm{E}$ ], $1482 \mathrm{~m}, 1898$, leg. Hauser (NHMW, cAss). Kazakhstan: $20^{\star 7} 0^{*}, 1$ ㅇ, Syrdaria river, Akkum, 11.VI.1985, leg. Kastcheev (cAss). Locality not specified: 2 exs., "Turcmenien", leg. Leder \& Reitter (NHMW, cAss).

The lectotype of Medon picinus Bernhauer, a junior synonym of S. nigrinus (EPPELSHeim), was designated by Assing (2008).

\section{Sunius praecisus AssING, 2008}

Material examined:

Tajikistan: 1 ex., "Saramsakli" (NHMW); 3 exs., Hissar mts., 1898, leg. Hauser (NHMW). Afghanistan: 1 ex., "Col de Sabnak[?]", 2450 m, 16.VI.1959, leg. Lindberg (cAss).

The species was previously known from Tajikistan and Iran (Assing 2008). It is here reported from Afghanistan for the first time.

\section{Sunius kastcheevi sp. n.}

(Figs 36-39)

\section{Type material:}

Holotype ơ: Kazakhstan, Aksu-Djabagly, Taldy-Bulak [river], 25.04.1979, V. Kastcheev / Holotypus o Sunius kastcheevi sp. n. det. V. Assing 2008 (cAss). Paratypes: 2 ㅇ 우: same data as holotype (cAss, cKas); 1 ơ $^{\star}$ S Kazakhstan,Karatau, Baizhansai, Boroldai riv., 13.06.1983, V. Kastcheev (cAss). 


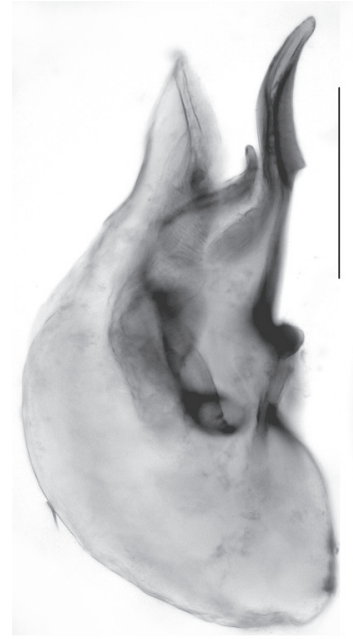

37

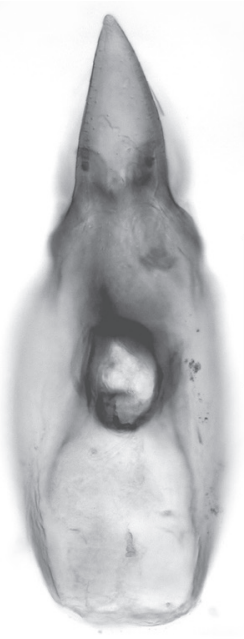

38

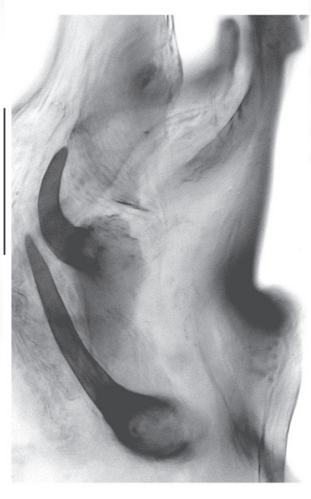

39

Figs 36-39: Sunius kastcheevi sp. n.: male sternite VIII (36); aedeagus in lateral and in ventral view (37-38); internal structures of aedeagus in lateral view (39). Scale bars: 36-38: $0.2 \mathrm{~mm}$; 39: 0.1 mm.

\section{Description:}

3.6-4.2 mm. Coloration: head black; pronotum dark brown to blackish; elytra dark brown with paler posterior margins; abdomen black, with posterior margin of segment VII and segments VIII-X slightly paler; yellowish-brown to dark brown; antennae brown to dark brown.

Head approximately 1.05 times as long as wide; punctation distinct, rather dense in anterior half and sparse in posterior half of dorsal surface; integument with only indistinct traces of microsculpture.

Pronotum approximately as wide as long and slightly (ca. $1.05 \mathrm{x}$ ) wider than head; punctation dense and slightly finer than that of head; midline impunctate; microsculpture absent.

Elytra approximately 1.25 times as wide and 1.15 times as long as pronotum; punctation much finer, denser, and less defined than that of pronotum. Hind wings fully developed.

Abdomen slightly narrower than elytra, widest at segment V; punctation dense and very fine; the whole surface with pronounced microsculpture and matt; posterior margin of tergite VII with palisade fringe.

$0^{\star}$ : sternite VII with weakly concave posterior margin, pubescence unmodified; sternite VIII posteriorly with U-shaped, margined incision (Fig. 36); aedeagus shaped as in Figs 37-38; apical part of ventral process long and distinctly bent in lateral view; internal structures of distinctive shape (Fig. 39).

\section{Etymology:}

The species is dedicated to Vitaly Kastcheev, Almaty, who collected the type series.

\section{Comparative notes:}

Based on the external morphology (coloration, habitus, punctation) and especially the male sexual characters (shape of posterior incision of sternite VIII; general morphology of aedeagus), the species undoubtedly belongs to the $S$. nigrinus group. From the species of this group ( $S$. nigrinus, $S$. praecisus, $S$. mordicus, $S$. afghanicus), all of which are distributed in Central Asia, S. kastcheevi is 


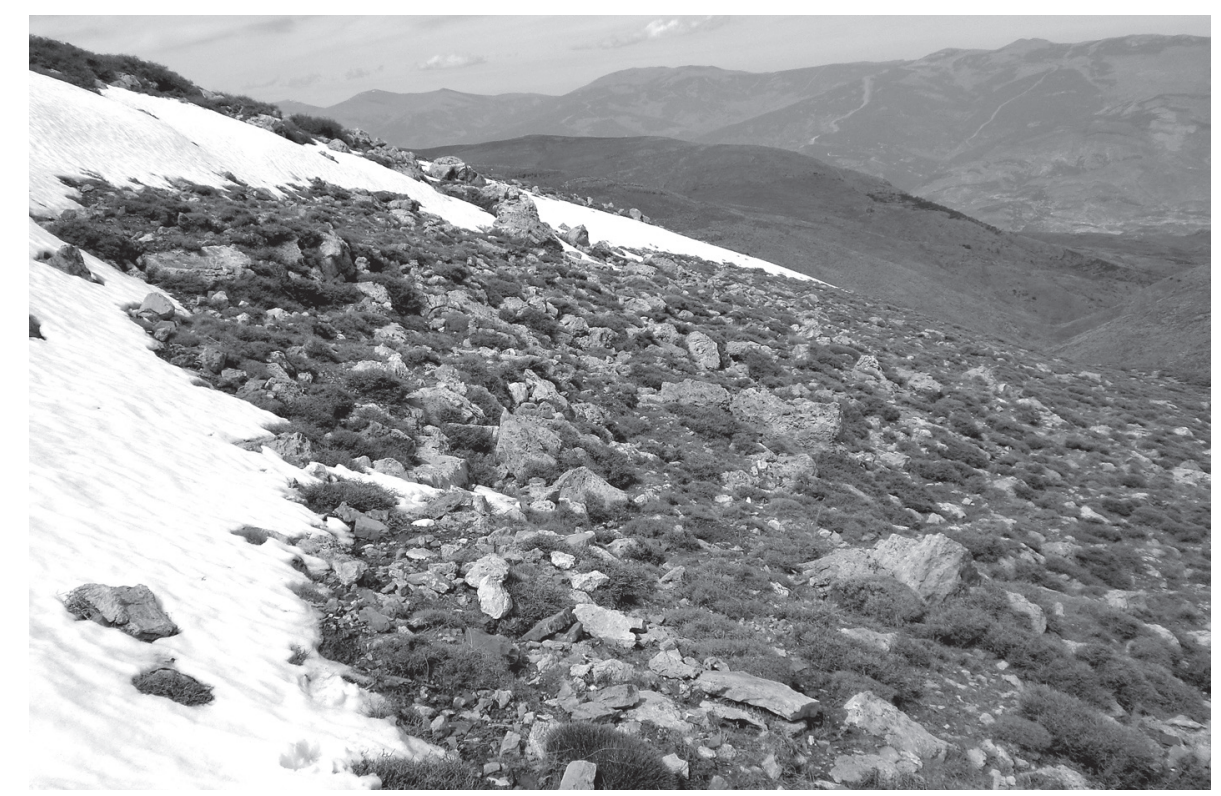

Fig. 40: Locality where 16 type specimens of Sunius gadoricus sp. n. were found (altitude: $2220 \mathrm{~m}$ ). The mountain range in the background is the Sierra Nevada.

reliably distinguished only based on the morphology of the aedeagus, especially the long and bent apical part of the ventral process and the shape of the internal structures. For illustrations of the male genitalia of the other representatives of the S. nigrinus group see Assing (2008).

\section{Distribution and bionomics:}

The type specimens were collected in two localities in southern Kazakhstan, to the northwest and southwest of Džambul. Bionomic data are not available.

\section{Sunius cordiformis Assing, 2002}

Material examined:

China: 1 ex., Sichuan, $24 \mathrm{~km}$ SE Lucheng ["Tatsien"], "Wa-Su-Kou", 2955', 102¹3'E ["2930'N, $103^{\circ} 00^{\prime} E^{\prime \prime}$, Tung river, $1600 \mathrm{~m}$, 5.X.1935, leg. Schäfer (NHMW); 1 ex., Yunnan, Lijiang, Hutiaoxia, stream bank litter, 14.IV.2003, leg. de Rougemont (cRou).

The species was previously known only from the Chinese provinces Beijing and Shaanxi (Assing 2002). It is here reported from Sichuan and Yunnan for the first time.

\section{Sunius claviceps (REITTER, 1908)}

? Medon nidicola KastcheEv, 1982: 537.

Sunius bogdoensis Grebennikov, 2001: 443 f., syn. n.

\section{Type material examined:}

M. nidicola: Paratype + [with heads of 4 additional specimens attached to the same pin]: [locality in Cyrillic], 30.10.78 / Paratypus Medon nidicola Kastcheev / Sunius cf. claviceps (Reitter) det. V. Assing 2008 (cKas). 
S. bogdoensis: Holotype $0^{\star}$ : Baskuntshak bl. gory, Bol. Bogdo [in Cyrillic], 14.IX.1996, K. A. Grebennikov / Holotypus Sunius bogdensis [sic] sp. n. K. Grebennikov det., 2000 / Zoological Institute RAS St. Petersburg / Sunius claviceps (Reitter) det. V. Assing 2008 (ZIN).

Additional material examined:

Uzbekistan: 1 ex., Tashkent (NHMW).

In external morphology, the examined paratype of $S$. nidicola (KastcheEv) resembles $S$. claviceps, suggesting that the former may be a synonym of the latter. However, since the holotype is a male and may be available for study in the future, a formal synonymisation is not proposed herein.

The original description of S. bogdoensis is based on a holotype male collected near Lake Baskuntshak ( $48^{\circ} 12^{\prime} \mathrm{N}, 46^{\circ} 53^{\prime} \mathrm{E}$; close to the border of Kazakhstan), Astrakhan province, in the lower Volga region. Its external and sexual characters are identical to those of S. claviceps, with which $S$. bogdoensis is herein synonymised.

Sunius claviceps is apparently rather widespread in Middle Asia; it was previously known from Kazakhstan, Uzbekistan, and Turkmenistan (Assing 2008) and is herein reported from Russia for the first time.

\section{Acknowledgements}

Thanks are extended to the colleagues listed in the materials section for the loan of material from their respective collections. In particular, I am grateful to Prof. Vitaly Kastcheev, Almaty, for the generous gift of Sunius material from Kazakhstan, including the type material of $S$. kastcheevi. Michael Schülke, Berlin, helped identifying the type locality of $S$. bogdoensis. Christopher Majka, Halifax, and Benedikt Feldmann, Münster, proof-read the manuscript.

\section{References}

Assing, V. 1995: Über Sunius fallax (LoKaY, 1919) (Coleoptera, Staphylinidae). - Entomologische Nachrichten und Berichte 38 (1994): 267-269.

Assing, V. 2002: New species of Sunius Curtis from China and Iran (Coleoptera: Staphylinidae, Paederinae). - Linzer biologische Beiträge 34: 289-296.

Assing, V. 2008: A revision of the Sunius species of the Western Palaearctic region and Middle Asia (Coleoptera: Staphylinidae: Paederinae). - Linzer biologische Beiträge 40: 5-135.

Grebennikov, K. A. 2001: Novye vidy stafilinid (Coleoptera, Staphylinidae) s nizhnego povolzh'ia. - Entomologicheskoe Obozrenie 80: 443-448.

Kastcheev, V. A. 1982: Novye vid' Zhukov-Stafilininov (Coleoptera, Staphylinidae) iz Pustyni Kyzylkum. - Entomologicheskoe Obozrenie 61: 537-541.

Author's address:

Dr. Volker Assing

Gabelsbergerstr. 2

30163 Hannover

Germany

e-mail: vassing.hann@t-online.de
Subject editor:

Dr. L. Zerche 